\title{
Maternal COVID-19 and neonatal hearing loss: a multicentric survey
}

\author{
Badr Eldin Mostafa ${ }^{1}\left[\right.$ D $\cdot$ Ahmed Mostafa $^{2} \cdot$ Lobna M. El Fiky $^{1} \cdot$ Abir Omara $^{2} \cdot$ Ahmed Teaima $^{1}$
}

Received: 6 August 2021 / Accepted: 16 September 2021 / Published online: 2 October 2021

(c) The Author(s), under exclusive licence to Springer-Verlag GmbH Germany, part of Springer Nature 2021

\begin{abstract}
Purpose Gestational SARS-Cov-2 infection can impact maternal and neonatal health. The virus has also been reported of causing sensorineural hearing loss. The objective of this study was to determine the possible effect of maternal SARS-COV-2 infection on neonatal hearing as identified during universal hearing screening.

Methods Retrospective cohort study in two tertiary referral centers including all neonates born from November 2020 through April 1st, 2021 and undergoing the universal hearing screening program. Maternal Covid-19 infection was recorded (timing and severity) and the results of hearing screening of their neonates compared to the incidence of neonatal hearing loss results of the national universal screening program during the same period.

Results A total of 984 neonates were included (508 males and 476 females). Sixty-three neonates were excluded due to comorbidities which could cause hearing loss. The incidence of failed responses in the community at large was $2.3 \%$. Twentyseven failed both steps of screening $(2.9 \% ; p<0.2)$. There were 34 Covid-19 positive mothers $(17$ in the first trimester, 8 in the second and 9 in the third). Twenty-nine neonates failed the first screening $(p<0.00001)$ but on further testing only one neonate failed $(2.9 \%)$.
\end{abstract}

Conclusion In this study, neonates born to Covid-19 positive mothers do not seem to have an increased risk of hearing loss. However longer follow-up of these neonates is mandatory to detect any possible delayed effects of the virus.

Keywords COVID-19 $\cdot$ Neonatal screening $\cdot$ Hearing loss

\section{Introduction}

Neurological affections have been reported during infections by the novel SARS-COV-2 virus. These include affections of smell, taste, hearing and balance, Bell's palsy, encephalitis, ischemic stroke, intracerebral hemorrhage, Guillain-Barre syndrome and a multitude of other more subtle manifestations[1-7]. With the evolution and persistence of the pandemic, pregnancies and deliveries were inevitable. The effects of the virus on pregnant ladies, pregnancy outcomes and neonatal health were studied. In a systematic review, variable pregnancy outcomes were detected: premature rupture of membranes, preterm labor, fetal distress and post-partum fever[8, 9]. Vertical neonatal infection seems to be uncommon but case reports indicate that placental and

Badr Eldin Mostafa

bemostafa@med.asu.edu.eg; bemostafa@gmail.com

1 Faculty of Medicine, Ain Shams University, 75 El Nozha Street, Heliopolis-Cairo 11351, Egypt

2 Hearing and Speech Institute, Giza, Egypt neonatal infection could occur, and that maternal infection is associated with placental changes [10-12]. Abundant scientific evidence demonstrates that maternal inflammation can cause a spectrum of lifelong sequelae in the offspring. Therefore, it is reasonable to speculate that the proinflammatory state of SARS-CoV-2 infection during pregnancy may precipitate negative consequences in children $[13,14]$. In addition to potential risk of vertical transmission, SARSCoV-2 may indirectly lead to adverse perinatal and longerterm neurodevelopmental outcomes $[15,16]$. The inner ear is a complex structure which starts to develop early during pregnancy (Carnegie stages 14-16) and progresses during early gestation. The third month is the critical period for ear development. Later, the fully developed inner ear may be vulnerable to infections or ototoxic insults[17]. Although current evidence suggests that COVID-19 infection during pregnancy rarely affects fetal and neonatal mortality [18-20], the constantly changing situation of the virus and its variants incited us to perform a survey of gestational COVID-19 infection and its effects on the incidence of 
Table 1 Neonatal hearing screening results

\begin{tabular}{lrrrrrr}
\hline Population & \multicolumn{1}{l}{ Total } & No comorbidities & Fail 1 & Pass & Fail 2 & Percentage \\
\hline Screened neonates & $1,800,000$ & $1,758,600$ & & & 41,400 & 2.3 \\
Cohort & 921 & 756 & 165 & 17.9 & 27 & 2.9 \\
COVID-19+ve & 34 & 5 & 29 & 85 & 1 & 2.9 \\
\hline
\end{tabular}

neonatal sensorineural hearing loss during universal hearing screening.

\section{Patients and methods}

This is a retrospective cohort study conducted in two tertiary referral centers (and their affiliated facilities). It included all neonates born between November 2020 and April 1st, 2021 who underwent newborn hearing screening. A comprehensive questionnaire was filled out at the screening facility to determine the COVID-19 status of the mother throughout pregnancy and the neonatal outcome as regards failed screening. Reported were other possible causes of neonatal hearing loss. The national program consists of TEOAE at the primary health care facility and ABR if the newborn did not pass the test. We excluded premature neonates (gestational age $<37$ weeks), neonates with congenital anomalies, craniofacial syndromes, exposure to ototoxic drugs, prolonged incubation, neonatal hypoxia, family history of congenital hearing loss or neonatal jaundice necessitating exchange transfusion. Results were compared with data of the national universal screening program during 2020. The study was granted exceptional emergency approval by both institutions' ethical committees.

\section{Results}

The study included 984 neonates who were subjected to the universal newborn hearing screening program. There were 508 males and 476 females. There were 16 multiple pregnancies (15 twins and 1 triplets), 23 cases of consanguinity $(2.7 \%)$. We excluded 63 cases with comorbidities which could affect hearing (6.4\%). Nine hundred and twenty-one neonates were thus included.

On primary screening, 165 neonates failed the screening [18\%] but only 27 failed ABR testing [2.9\%]. This result is statistically comparable to the national standard (2.3\%). (The chi-square statistic is 1.6339 . The $p$ value is 0.20116 . Not significant at $p<0.05)$.

There were 34 cases reporting a + COVID infection in the cohort [3.45\%]. Seventeen ladies were infected in the first trimester, eight in the second and nine in the third. Twentytwo were hospitalized for moderate to severe infection. The ten neonates tested for Covid-19 were negative. Among the neonates born to COVID-19 positive mothers 29 failed the primary screening and were referred to further testing. Compared to the study population and the national standard, the difference was statistically significant $(p<0.00001)$. However, on retesting, only one neonate failed $(2.9 \%)$. Compared to the tested cohort and the national standards this finding is statistically insignificant ( $p=0.87132$ and $p=0.20116$, respectively) (Table 1 ).

\section{Discussion}

Pregnancy is a very specific condition as maternal and neonatal health and safety are at stakes [14, 21, 22]. The effects of COVID-19 infection on pregnant ladies and neonatal outcomes are variable and contradictory. Most studies report no ill-effects on either mother or newborn and no evidence of transplacental or vertical transmission [23]. In a few studies, premature labor, low birth weight or neonatal asphyxia were reported [24-30]. However, with the evolution of the pandemic, various neurotropic effects of the virus have been reported [1-3, 6, 31, 32]. Although hearing loss due to COVID-19 was reported in few case reports [31, 33-35], the developing ear may be at risk because of maternal infection during pregnancy or as a post-natal event $[10,36,37]$. This study was conducted to seek the impact of maternal COVID19 infection throughout pregnancy on the neonatal hearing outcomes as reported during the universal newborn hearing screening program. Egypt reported the first cases of COVID19 on February 14th, 2020, and lockdown measures were enforced on March17th. During 2020, the number of births in Egypt was around 3.6 million live births (4\% decline from 2019). The total number of reported infections in Egypt was 284 thousand cases with half of the infections reported in patients aged 18-50. The proportion of males/females in both the general population and infected patients is nearly $1: 1$ the number of infected females in the childbearing age would be around 71 thousand with an infection rate around $0.59 \%$. The total number of neonates undergoing universal screening was around 1.8 million neonates with an overall fail rate of $2.3 \%$ [38-40].

In our study population, there were 34 COVID-19 pregnant ladies $(3.4 \%)$ which is much higher compared to a national reported rate of $(0.286 \%)$ for females in the reproductive age[38, 41]. This marked discrepancy can be explained by the societal concern over pregnancy with 
concerns over the mother and child and immediate request for medical advice. The rate of neonatal hearing affection as detected during newborn hearing screening was globally like the national rate in both the studied cohort and in the neonates born to COVID-19 positive mothers. The only observation is the higher rate of failed tests on primary screening. It is possible that the higher incidence was due to technical difficulties as health workers in contact with COVID-19 positive patient were usually in full PPE gear and extremely cautious in handling the neonates. There were no differences on neonatal outcomes regarding the time of infection during gestation. This result is different from the data reported in another study [42] but larger multicentric and multinational studies are needed.

\section{Conclusion}

Although these primary results do not indicate any immediate effect of SARS-COV-2 maternal infection on neonatal hearing, more children need to be tested and followed up over an extended period of time to detect any possible delayed effects [6, 7]. Early automated ABR rather than TOEA only may detect auditory neuropathy as one of the neuropathic effects of the virus.

\section{References}

1. Degen C, Lenarz T, Willenborg K (2020) Acute profound sensorineural hearing loss after Covid-19 pneumonia. Mayo Clin Proc 95:1801-1803

2. Kilic O, Kalcioglu MT, Cag Y, Tuysuz O, Pektas E, Kaskurlu H, Cetin F (2020) Could sudden sensorineural hearing loss be the sole manifestation of COVID-19? An investigation into SARSCOV-2 in the etiology of sudden sensorineural hearing loss. Int J Infect Dis 97:208-211. https://doi.org/10.1016/j.ijid.2020.06.023

3. Essmat A (2021) Neurological Manifestations in Egyptian Covid-19 Patients. Al Azhar International Medical Journal 1(12):259-261

4. Ellul MA, Benjamin L, Singh B, Lant S, Michael BD, Easton A, Kneen R, Defres S, Sejvar J, Solomon T (2020) Neurologic associations of COVID-19. Lancet Neurol 19:766-783

5. Yachou Y, El Edrissi A, Belapasov V, AinBenali S (2020) Neuroinvasion, neurotropic, and neuroinflammatory events of SARSCoV-2: understanding the neurological manifestations in COVID19 patients. Neurol Sci 41(10):2657-2669

6. Almufarrij I, Uus K, Munro KJ (2020) Does coronavirus affect the audio-vestibular system? A rapid systematic review. Int J Audiol 59(7):487-491. https://doi.org/10.1080/14992027.2020.1776406

7. Nepal G, Rehrig JH, Shrestha GS, Shing YK, Yadav JK, Ojha R, Pochrel G, Tu ZL, Huang DY (2020) Neurological manifestations of COVID-19: a systematic review. Crit Care 24(421):1-11. https://doi.org/10.21203/rs.3.rs-37601/v1

8. Yoon SH, Kong JM, Ahn JG (2020) Clinical outcomes of 201 neonates born to mothers with COVID-19: a systematic review. Eur Rev Med Pharmacol Sci 24(14):7804-7815. https://doi.org/ 10.26355/eurrev_202007_22285
9. Norman M, Naver L, Soderling J, Ahlberg M, Hervius Askling $\mathrm{H}$, Aronsson B, Bystrom E, Jonnson J, Sengpiel V, Ludvigsson JF, Hakansson S, Stephansson O (2021) Association of maternal SARS-CoV-2 infection in pregnancy with neonatal outcomes. JAMA. https://doi.org/10.1001/jama.2021.5775

10. Prochaska, E., Jang, M. and Burd, I. (2020) 'COVID-19 in pregnancy: Placental and neonatal involvement. Am J Reproduct Immunol. https://doi.org/10.1111/aji.13306

11. Figueiro-Filho EA, Yudin M, Farine D (2020) COVID-19 during pregnancy: An overview of maternal characteristics, clinical symptoms, maternal and neonatal outcomes of 10,996 cases described in 15 countries. J Perinat Med 48(9):900-911. https:// doi.org/10.1515/jpm-2020-0364

12. Schwartz DA (2020) An analysis of 38 pregnant women with COVID-19, their newborn infants, and maternal-fetal transmission of SARS-CoV-2: maternal coronavirus infections and pregnancy outcomes. Arch Pathol Lab Med 144(7):799-805. https:// doi.org/10.5858/arpa.2020-0901-SA

13. Penfield CA, Brubaker SG, Limaye MA, Lighter J, Ratner AJ, Thomas KM, Meyer JA, Roman AS (2020) Detection of severe acute respiratory syndrome coronavirus 2 in placental and fetal membrane samples. Am J Obst Gynecol MFM 2(3):100133. https://doi.org/10.1016/j.ajogmf.2020.100133

14. Alzamora MC, Paredes T, Caceres D, Webb CM, Valdez LM, Larosa M (2020) Severe COVID-19 during pregnancy and possible vertical transmission. Am J Perinatol 37(8):861-865

15. Kumari K, Yadav R, Mittra S, Kumar A, Singh J, Bajpai RK, Srivastava DK, Kumar R (2021) Pregnancy consequences and vertical transmission potential of SARS- CoV-2 infection: seeking answers from a preliminary observation. J Reproduct Infert. https://doi.org/10.18502/jri.v22i2.5804

16. Cai J, Zhang Y, Tang M (2021) New evidences that discard the possible vertical transmission of SARS-CoV-2 during pregnancy. Med Clin 156(10):523. https://doi.org/10.1016/j.medcli. 2020.09.021

17. Lavigne-Rebillard M, Dechesne C, Pujol R, Sans A, Escudero P (1985) Development of the internal ear during the 1st trimester of pregnancy. Differentiation of the sensory cells and formation of the 1 st synapses. Annales d'oto-laryngologie et de chirurgie cervico faciale : bulletin de la Société d'oto-laryngologie des hôpitaux de Paris 102(7):493-498

18. Saleh Elhalik M (2020) Clinical profile of neonates delivered from mothers with confirmed COVID-19 infection: An experience from a Tertiary Perinatal Care Center in Dubai, UAE. J Pediatr Neonatal Care. https://doi.org/10.15406/jpnc.2020.10. 00427.

19 Vaezi M, Mirghafourvand M, Hemmatzadeh M (2021) 'Characteristics, clinical and laboratory data and outcomes of pregnant women with confirmed SARS-CoV-2 infection admitted to AlZahra tertiary referral maternity center in Iran: a case series of 24 patients. BMC Pregnancy Childbirth. https://doi.org/10.1186/ s12884-021-03764-y

20. Saeedi M, Sangsari R, Mirnia K (2021) Covid-19 in neonates: a review. Iran J Pediatr 31(1):1-9. https://doi.org/10.5812/ijp. 104423

21. Silasi M, Cardenas I, Kwon JY, Racicot K, Aldo P, Mor G (2015) Viral infections during pregnancy. Am J Reproduct Immunol 73:199-213. https://doi.org/10.1136/bmj.2.5298.192-a

22. Barrero-Castillero AB, KS, Bernardini LB, Ramos ECG, Davenprot PE, Duncan AR Fariman YS Frazer LC, Healy H, Herzberg EM, Kayes ML, Leeman KT, Leone K, Lin M, Raju RM, Sullivan A. (2021) COVID-19: neonatal-perinatal perspectives. J Perinatol 41(5):940-951. https://doi.org/10.1038/s41372-020-00874-x

23. Hayakawa S, Komine-Aizawa S, Mor GG (2020) Covid-19 pandemic and pregnancy. J Obst Gynaecol Res 46(10):1958-1966. https://doi.org/10.1111/jog.14384 
24. Gale C, Quigley MA, Placzek A, Knight M, Ladhani S, Draper ES, Sharkey D, Doherty C, Mactier H, Kurinczuc JJ (2021) Characteristics and outcomes of neonatal SARS-CoV-2 infection in the UK: a prospective national cohort study using active surveillance. Lancet Child Adolescent Health 5(2):113-121. https://doi.org/10. 1016/S2352-4642(20)30342-4

25. Zha Y, Chen G, Gong X, Wu YY, Lin XG, WU JL, Huang YF, Li YQ, Zhang Y, Deng DR, Chen SH, Quao FY, Feng L, Zeng WJ, Li KZ, Liu HY. (2021) Coronavirus disease 2019 in pregnant and non-pregnant women: a retrospective study. Chin Med J 134(10):1218-1220. https://doi.org/10.1097/CM9.0000000000 001396

26. Yu N, Wei L, Kang Q, Xiong Z, Wang S, Lin X, Xiao J, Liu H, Deng D, Chen S, Zeng W, Feng L, Wu J (2020) Clinical features and obstetric and neonatal outcomes of pregnant patients with COVID-19 in Wuhan, China: a retrospective, single-centre, descriptive study. Lancet Infect Dis 20(5):559-564. https://doi. org/10.1016/S1473-3099(20)30176-6

27. Za Y, Chen G, Gong X, Wu YY, Lin XG, Wu JL, Huang YF, Li YQ, Zhang Y, Deng DR, Chen SH, Quiao FY, Feng L, ZHeng WJ, Li KZ, Liu HY. (2021) Corona virus disease 2019 in progress. Chin Med J 134(10): 1218-1221

28. Trevisanuto D, Cavallin F, Cavicchioli ME, Borrellini M, Calgaro S, Baraldi E (2021) Corona virus in neonates : a systematic review. Arch Dis Child Fetal Neonatal 106:F330-F335

29. Zimmerman P, Curtis N. (2020) COVID-19 in children, pregnancy and neonates: a review of epidemiologic and clinical features. Pediatr Infect Dis J, pp 469-477.

30. Katz D, Bateman BD, Kjaer K (2021) 'An analysis of outcomes among pregnant women delivering during the initial severe acute respiratory syndrome coronavirus-2 outbreak in the United States. Anaes Analg 133(2):462-473

31. Mustafa MWM (2020) Audiological profile of asymptomatic Covid-19 PCR-positive cases. Am J Otolaryngol Head Neck Med Surg 41(3):1-3. https://doi.org/10.1016/j.amjoto.2020.102483

32. Stafstrom CE, Jantzie LL (2020) COVID-19: neurological considerations in neonates and children. Children 7(9):133. https:// doi.org/10.3390/children7090133

33 Koumpa F, Forde C, Manjaly J (2020) Sudden irreversible hearing loss post COVID-19. BMJ Case Rep 13(11):e238419
34. Beckers E, Chouvel P, Cassetto M, Mustin V (2021) Sudden sensorineural hearing loss in COVID-19: a case report and literature review. Clin Case Rep 9(4):2300-2304

35. Alves de Sousa F, Pinto Costa S, Xara S, Nobrego Pinto A, Almeida de Sousa C (2021) SARS-CoV-2 and hearing: an audiometric analysis of COVID-19 hospitalized patients. J Otol 16(3):158-164

36. Marcdante KJ, Kliegman RM (2019) Congenital infections. In Nelson's Essential of Pediatrics. 8th edn. Elsevier, Amsterdam, pp 259-64

37 Raschetti R, Vivanti AJ, Vauloup-Fellous C, Loi B, Benachi A, De Luca D (2020) Synthesis and systematic review of reported neonatal SARS-CoV-2 infections. Nat Commun. https://doi.org/ 10.1038/s41467-020-18982-9

38. Kassas M, Asem N, Abdelazeem A, Madkour A, Sayed H, Tawheed A, Shafie A, Gamal M, Elsayed H, Badr M, Hassany M, Omran D, Fouly A (2020) Clinical features and laboratory characteristics of patients hospitalized with COVID-19: Single centre report from Egypt. J Infect Dev Ctries 14(12):1352-1360. https://doi.org/10.3855/jidc. 13156

39. Dong U, Du H, Gardner L (2020) An interactive web-based dashboard to track COVID-19 in real time. Lancet Infect Dis 20(5):533-534

40. CAPMAS Central Agency for Public Mobilisation and Statistics (no date) No Title. Available at: https://www.capmas.gov.eg/ Pages/IndicatorsPage.aspx?page_id=6135\&ind_id=1097

41. Gajbhyie RK, Sawant MS, Kuppusami P (2021) Differential impact of Covid-19 in pregnant women from high income countries and low to middle income countries: a systematic review and meta-analysis. Int J Gynaecol Obstet

42. Alan MA, Alan C (2021) Hearing screening outcomes in neonates of SARS-CoV-2 positive pregnant women. Int J Pediatr Otorhinolaryngol. https://doi.org/10.1016/j.ijporl.2021.110754

Publisher's Note Springer Nature remains neutral with regard to jurisdictional claims in published maps and institutional affiliations. 